\title{
Species List of Quadroppiidae (Acari: Oribatida) with Descriptions of a New Genus and two New Species
}

\author{
Norihide OHKUBO \\ Mie Agricultural Research Center, Ureshino-cho, Mie, 515-23 Japan.
}

(Received 12 May 1995; Accepte 22 June 1995)

\begin{abstract}
Ohkubo, N., 1995. Species list of Quadroppiidae (Acari: Oribatida) with descriptions of a new genus and two new species. J. Acarol. Soc. Jpn., 4(2): 77-89.

All hitherto known species and subspecies of the genus Quadroppia are listed up and separated into Quadroppia s. str. and Coronoquadroppia nov. gen. Two new species, C. parallela and C. expansa are described from Japan; the former is the type species of the genus.
\end{abstract}

Key words: oribatid mites, Quadroppiidae, Quadroppia, Coronoquadroppia n. g., new species, new combinations

\section{INTRODUCTION}

The family Quadroppiidae Balogh, 1983 has been represented by a single genus Quadroppia. After Mínguez et al. (1985) published a monograph of the genus Quadroppia, some more species have been added to this genus. Over 20 species are known at present. Woas (1986) considered that Hexoppia Balogh, 1958 was a synonym of Quadroppia. However, I regard Hexoppia as a valid genus which does not belong even to the family Quadroppiidae, because its ventral feature is greatly different from that of Quadroppia. Species so far relegated to the genus Quadroppia can be clearly separated into two groups, according to the prodorsal feature. It is adequate to remove one of the groups from Quadroppia to make a new genus. All hitherto known species and subspecies of Quadroppiidae are also reviewed.

\section{Family Quadroppiidae Balogh, 1983}

Quadroppiinae Balogh, 1983

Quadroppiidae: J. Balogh and P. Balogh (1992)

Type genus: Quadroppia Jacot, 1939

Remarks. The members of Quadroppiidae are very small and have complicated structures on prodorsum and notogaster. This is the reason why the taxonomy of these mites is difficult and confused. Some problematic but important characters are as follows: 
Frons. Frons is an anterior region of prodorsum in front of translamella, loading either frontal appendage or frontal mound. Details of these structures are difficult to see in dorsal view, because the contour of frons in lateral view is strongly curved. The true shape of frons would be well observed in antero-dorsal view. In many figures drawn by the previous authors, the appendage is closed anteriorly. Apparently, $Q$. nasalis Gordeeva, 1983 has an anteriorly closed appendage, as its lateral view in the original figures shows. It is, though, doubtful whether or not it is truly closed anteriorly in some other species. In two Japanese species which have anteriorly opened appendages as described later, the anterior part would be sometimes looked closed in dorsal view.

Lamella. The whole shape of lamella unified with a bothridium appeals that the structure is not a costula but a true lamella. The presence of lamellae justifies the separation of the family Quadroppiidae from the Oppiidae. A flat, lamellar plate is loaded on the anterior tip of each lamella. Although the shape of the plate and the length between two plates are important as specific characters, the plates are so thin that the observation through transparent illumination would be difficult. The border between the plate and the translamella sometimes disappears like in Q. quadricarinata. Lamellar setae are located on the prodorsal surface, free from the plates.

Translamella. Lamellar plate is easily mistaken for a part of translamella. Both ends of translamella are concealed under lamellar plates. Prodorsal surface is fairly concave in front of translamella.

Interlamellar region. The region is separated into the anterior and posterior parts by a transverse groove situated in front of interlamellar setae. Each part contains the mound which is separated from lamellae by grooves.

Bothridium. Bothridial protuberance strongly develops postero-laterally. Characteristic features are especially found in the lateral aspect of an upper end of a rim. The anterior side of the sensillar head is so fragile that it is easily crushed flat. Barbs would show a specific feature.

Prodorsal setae. Rostral setae are either smooth or barbed at basal half or at the middle; the barbs are fairly minute. Other prodorsal setae are smooth. Lamellar setae are free from lamellar plates, being nearly decumbent. Interlamellar setae direct upward. Exobothridial setae $e x$ are located just near an upper ridge of acetabular tectum I, directing forward.

Lateral features. Fundamental important ridges are upper pleural ridge, anterior pleural ridge, genal ridge, upper ridge of acetabular tectum I, anterior cross ridge and posterior cross ridge. A lobe of acetabular tectum I develops widely at upper and anterior part; border between the lobe and tectum is sometimes obscure. A lobe of acetabular tectum III is kidney-shaped, very large, extended laterad.

Epimeral region. The shapes of sternal grooves I and III are characteristic of some species. A pit is situated in sternal groove I. Sternal apodeme II is absent; sternal apodemes I and III are narrower than sternal grooves. Epimeral groove II possesses three to four pits at each side; sejugal groove possesses four to five pits. Epimeral groove III is very obscure and incomplete, only detectable by SEM, separating epimera 
III and IV; apodeme III is absent. The family Quadroppiidae can be distinguished from the Oppiidae also by the presence of epimeral groove III. Under transmitted illumination, two transverse darkened zones are observed behind a line of setae $4 a$ and $4 b$. The anterior zone is a posterior border of epimeron IV, and the posterior one is apodeme IV; epimeral groove IV is located between the two zones. Exterior lateral borders of epimeral plates are steeply sloped, making edges; the edge is especially conspicuous at epimera III and IV. Epimeral setae are smooth. Setal formula is 3-1-3-3. Seta $1 c$ is on pedotectum I; $3 c$ on custodium; $4 c$ on discidium.

Notogaster. A pair of cristae and a U-shaped groove yield so many lines according to viewpoints. Interior and exterior borders of a crista seem to be ridged, but the crista is a single ridge with a wide and flat dorsal side. One or two more ridge-like shadows can be observed outside the crista. These are derived from a mere expansion along the lateral border of notogaster; the expansion could not be a ridge in an exact sense. A deep groove is present between the crista and the expansion. As a U-shaped line is a groove continued from the above groove, it would become clear or obscure according to the viewpoints. In postero-dorsal view, for example, the posterior part of the Ushaped groove would not be observed. When the interior edge of the groove is clearly seen, the line would be continued from the exterior border of the crista. If the exterior edge of the groove is clear, the line would be continued from the interior border of the lateral expansion. The groove is open to a notogastral border at its anterior end, abruptly widened and deepened behind seta $c_{2}$, then narrowed again, gradually shallowed, and obscured between setae $r_{2}$.

Nine pairs of setae are smooth with sharply pointed tips. Seta $c_{2}$ is situated on a lateral side of crista. Setae $t i, t e, m s, r_{2}$ and $r_{3}$ are located inside U-shape groove, while setae $r_{1}, p_{1}$ and $p_{2}$ are located outside the groove. Seta $p_{2}$ is decumbent. A pair of minute oil glands gla are located exterior to te.

Genus Quadroppia Jacot, 1939

Quadroppia Jacot, 1939

Type species: Notaspis quadricarinata Michael, 1885. For the fixation of type species, Jacot (1939) cited the redescription of this species given by Michael (1888). Two drawings were newly added in the redescription, but the dorsal figure and the text were apparently based on the original description in 1885 . The type species is, therefore, exactly the one published in 1885 .

Remarks. Frontal appendage in front of translamella is absent. Sometimes, frontal mound is present instead of the appendage. The border of the mound is not edged. Members are listed below in chronological order of specific names.

Quadroppia quadricarinata (Michael, 1885)

Notaspis quadricarinata Michael, 1885

Dameosoma quadricarinatum: Berlese (1896) 
Oppia quadricarinata: Willmann (1931)

Oppiella quadricarinata: Seniczak (1975)

Quadroppia quadricarinata: Jacot (1939)

Type locality. UK.

Remarks. As the original description was so incomplete, many other congeners might have been misidentified with this species for a long time. A description of its subspecies virginalis by Lions (1978 and 1982) is most useful to understand specific characters for this species. A good redescription was also presented by Woas (1986). Since the holotype had not been designated, Luxton (1987) chose a lectotype and gave its description. According to a personal letter from Dr. Luxton, the lectotype coded 1930.8.25.734 (not the code given in his previous paper) comes from the series of four slides in the Michael Collection of the Natural History Museum, London and is, therefore, from the syntype series. Since his designation of the lectotype is considered to be valid, the remaining syntypes became paralectotypes.

\section{Quadroppia quadricarinata virginalis Lions, 1982}

\section{Quadroppia quadricarinata form A: Lions (1978)}

Type locality. France.

Remarks. This subspecies was described together with Q. quadricarinata maritalis, but no discriminative features differentiating these two subspecies from the nominotypical one were presented. Later, Q. quadricarinata maritalis was raised to a species (Luxton, 1987). A figure of epimeral region was first given by Mínguez et al. (1985). Dorsal and ventral aspects were drawn by Subías and Rodríguez (1986), who also did not show any difference between this subspecies and the nominotypical one. Luxton (1987) who designated the lectotype of Q. quadricarinata seems to have considered that virginalis is the well-separable taxon as a subspecies. He, though, did not show the discriminative characters for these subspecies.

Quadroppia illinoisensis (Jacot, 1938)

Oppia quadricarinata illinoisensis Jacot, 1938

Quadroppia illinoisensis: Jacot (1939)

Type locality. USA.

Remarks. Jacot (1938b) figured a ridge just in front of translamella. I do not think it the frontal appendage, because it is too small. It would be a frontal mound.

\section{Quadroppia skookumchucki Jacot, 1939}

Quadroppia quadricarinata: Mínguez, Ruiz et Subías, (1985)

Type locality. USA.

Remarks. Though Mínguez et al. (1985) considered that Q. skookumchucki was synonymous to $Q$. quadricarinata, the two species can be distinguished from each other 
by the location of notogastral setae $r_{3}$ and the body size.

Quadroppia cristata Balogh et Mahunka, 1980

Type locality. Cuba.

Remarks. A round ridge near rostrum might be a frontal mound. Extremely long interior border of notogastral cristae of this species can not be found in other congeners.

Quadroppia maritalis Lions, 1982

Quadroppia quadricarinata form B: Lions (1978)

Quadroppia quadricarinata maritalis Lions, 1982

Quadroppia maritalis: Luxton (1987)

Type locality. France.

Remarks. The studies of Lions (1978 and 1982) are excellent and useful in the identification of this species.

Quadroppia hammerae Mínguez, Ruiz et Subías, 1985

Type locality. Spain.

Remarks. In the original description of this species, some features of Q. quadricarinata sensu Hammer, 1968 were cited. The authors of Q. hammerae, though, excluded her specimens from "Material estudiad". The Hammer's species thus should not be counted in the type series of this species.

I had an opportunity to observe two paratypes labeled as " $\mathrm{BP} 8, \mathrm{E} 1$ Pardo (MADRID), 31.I.78, M.E. Minguez leg, Base de Pino." Some features indicated in the original description should be corrected. The translamella in the original description contained two plates at lamellar tips. True translamella is very short between the plates. The plate is almost oval. The "punteado" is not a bit but a granule which is distributed more widely than originally figured. A pair of short ridges outside the lamellae are free from lamellar tips and lateral ridges.

Quadroppia longisetosa Mínguez, Ruiz et Subías, 1985

Type locality. Spain.

Remarks. Extremely long notogastral setae are characteristic of only this species.

Quadroppia longisetosa obsoleta Mínguez, Ruiz et Subías, 1985

Type locality. Spain. 
Genus Coronoquadroppia gen. nov.

Type species: Coronoquadroppia parallela sp. nov.

Remarks. The present new genus closely resembles Quadroppia but is easily distinguished from it by the frontal appendage which appears in front of translamella. The appendage protrudes from the prodorsal surface like a plateau and at least its lateral borders are strongly edged. The following species listed in chronological order become the members of this genus. Some of them are impossible to be distinguished from one another, because their descriptions were so incomplete.

Coronoquadroppia ferrumequina (Jacot, 1938) comb. nov.

Oppia quadricarinata ferrumequina Jacot, 1938

Quadroppia ferrumequina: Jacot (1939)

Type locality. USA.

Remarks. No figure has been drawn yet for this species. Though its original description gives no information whether a frontal appendage exists or not, the species seems to have such a structure according to the explanation by Jacot (1939) and the observation by Lions (1982). Therefore, the species might belong to this genus. The original description is quite useless to distinguish this species from other congeners.

Coronoquadroppia circumita (Hammer, 1961) comb. nov.

Oppia circumita Hammer, 1961

Quadroppia circumita: Hammer (1968)

Type locality. Peru.

Remarks. This species was described from Peru, and was later recorded also from New Zealand by the same author (Hammer, 1961 and 1968). Frontal appendages, though, were drawn in a little different way between the two figures that she gave in the above papers. According to the figures, the type specimen in Peru showed a frontal appendage that was dentated laterally and opened posteriorly, while the appendage possessed smooth borders and was closed posteriorly for a specimen from New Zealand. There is a possibility that Hammer misidentified the specimens from New Zealand. Mínguez et al. (1985) gave a figure of epimeral region for the first time, but they used the specimens that Hammer had collected in New Zealand. If Hammer had misidentified the specimens from New Zealand, their figure of the epimeral region would not be of $C$. circumita.

Coronoquadroppia michaeli (Mahunka, 1977) comb. nov.

Quadroppia michaeli Mahunka, 1977

Type locality. Greece.

Remarks. As Mínguez et al. (1985) pointed out, "Abb. 13" in the original description is 
the figure of this species and "Abb. 12" is not. They gave a figure of epimeral region for the first time.

\section{Coronoquadroppia monstruosa (Hammer, 1979) comb. nov.}

Quadroppia monstruosa Hammer, 1979

Type locality. Indonesia.

Remarks. This species is very similar to C. michaeli but is distinguishable from it by a wider interspace between two lamellar plates. Epimeral region is drawn by Mínguez et al. (1985) for the first time. They considered the figure, "Abb.12" of Mahunka (1977) as this species, though the species in the figure is a little different from the original one in the position of notogastral setae. If their identification was wrong, their figure of the epimeral region would not be of $C$. monstruosa.

Coronoquadroppia nasalis (Gordeeva, 1983) comb. nov.

Quadroppia nasalis Gordeeva, 1983

Type locality. Ukraine (former USSR).

Remarks. Extremely developed frontal appendage characterizes this species.

Coronoquadroppia media (Gordeeva, 1983) comb. nov.

Quadroppia media Gordeeva, 1983

Type locality. Georgia (former USSR).

Remarks. A long distance between genital and anal apertures is a characteristic feature of this species, if the original drawing was precise.

Coronoquadroppia nana (Gordeeva, 1983) comb. nov.

Quadroppia nana Gordeeva, 1983

Type locality. Georgia (former USSR).

Remarks. This species is small and narrow. Anteriorly widened frontal appendage is characteristic.

Coronoquadroppia omodeoi (Mahunka et Paoletti, 1984) comb. nov.

Quadroppia omodeoi Mahunka et Paoletti, 1984

Type locality. Italy.

Remarks. This species is very similar to C. michaeli.

Coronoquadroppia crenata (Mahunka, 1984) comb. nov.

Quadroppia crenata Mahunka, 1984 
Type locality. Tanzania.

Remarks. This species is very similar to C. monstruosa.

Coronoquadroppia pseudocircumita (Mínguez, Ruiz et Subías, 1985) comb. nov.

Quadroppia pseudocircumita Mínguez, Ruiz et Subías, 1985

Type locality. Spain.

Remarks. Dorsal and ventral aspects were given by Subías and Rodríguez (1986).

Coronoquadroppia pseudocircumita galaica

(Mínguez, Ruiz et Subías, 1985) comb. nov.

Quadroppia pseudocircumita galaica Mínguez, Ruiz et Subías, 1985

Type locality. Spain.

Coronoquadroppia paolii (Woas, 1986) comb. nov.

Damaeosoma quadricarinatum: Paoli (1908)

Quadroppia paolii Woas, 1986

Type locality. Germany or Italy (not designated).

Remarks. This species is very similar to C. michaeli.

When Woas (1986) established this species, the description was wholly based on his own specimens. However, he wrote as "Quadroppia paolii nom. nov. (=Dameosoma quadricarinatum Paoli, 1908)." This means that Q. paolii can be regarded as a species based partly on D. quadricarinatum sensu Paoli. According to Article 72b(ii) of International Code of Zoological Nomenclature (3rd ed., 1985), therefore, the type series should consist of both Woas's and Paoli's collections. He did not designate the holotype.

Coronoquadroppia bellula (Luxton, 1987) comb. nov.

Quadroppia bellula Luxton, 1987

Type locality. UK.

Remarks. This species is very similar to $C$. michaeli but the head of sensillus is smooth.

Coronoquadroppia abchasica (Gordeeva et Tarba, 1990) comb. nov.

Quadroppia abchasica Gordeeva et Tarba, 1990

Type locality. Georgia (former USSR).

Remarks. The authors compared this species to $C$. nasalis and showed distinguishing characters for them. 
Coronoquadroppia gumista (Gordeeva et Tarba, 1990) comb. nov.

Quadroppia gumista Gordeeva et Tarba, 1990

Type locality. Georgia (former USSR).

Remarks. Genital and anal apertures are extraordinarily separated, if the original figure was precise.

Coronoquadroppia ritza (Gordeeva et Tarba, 1990) comb. nov.

Quadroppia ritza Gordeeva et Tarba, 1990

Type locality. Georgia (former USSR).

Remarks. This species is very similar to $C$. michaeli.

\section{Coronoquadroppia parallela sp. nov.}

(Fig. 1)

Measurements. Mean body length $200 \mu \mathrm{m}$ for five specimens; width $113 \mu \mathrm{m}$ for three specimens.

Prodorsum. Rostrum round. Rostral setae smooth. Frontal appendage rectangular from antero-dorsal view; the posterior and lateral border strongly edged and irregularly dentated; the anterior border incomplete and obscure. Lamellar seta about as long as lamellar plate, located under the middle point of lamellar plate. Lamellar plate somewhat triangular with irregularly dentated borders. Translamella connecting the middle parts of the lamellar plates, almost straight, 1.4 to 1.5 times as wide as the plate. Anterior interlamellar mound somewhat rectangular. Interlamellar setae minute. Upper pleural ridge crescent, almost touching the frontal appendage; its interior side deeply excavated to make a pocket. Anterior pleural ridge reaching to the frontal appendage in dorsal view, curving anteriad. Genal ridge short. Exobothridial seta minute.

Bothridium. In lateral view, upper end of rim somewhat rectangular. Anterior corner above a slit sharply pointed; posterior corner rounded. Posterior slit V-shaped, well observed. Sensillar head with small, dense barbs.

Lateral podosoma. Border between acetabular tectum I and its lobe obscure. Lobe of acetabular tectum I curved along the tectum, with a round tip directing downward; its upper borderline a little obscure behind anterior pleural ridge. Upper ridge of acetabular tectum I crescent at middle part and roundly curved as a whole. Upper border of pedotectum I concave. Anterior cross ridge narrow, arranged at upper level than posterior cross ridge.

Epimeral region. Sternal groove I trapezoidal; its anterior border obscure. Sternal groove III longer than wide; lateral borders straight, slightly narrower posteriorly. Lateral borders of epimera III and IV smoothly continued; no concavity observed between two epimera.

Notogaster. In dorsal view, anterior part of crista somewhat rectangular. Interior 


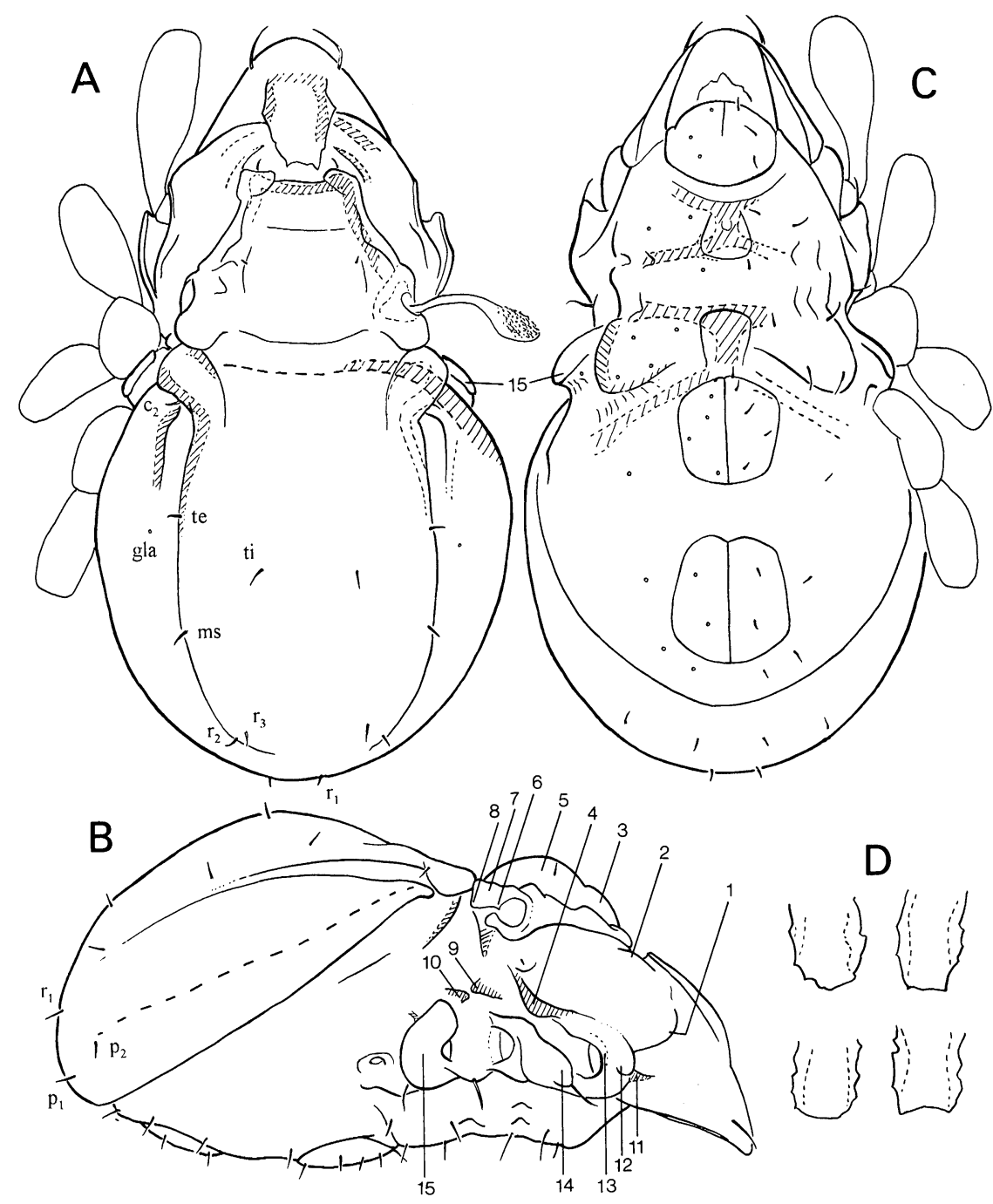

Fig. 1. Coronoquadroppia parallela gen.nov. and sp.nov. A: Dorsal view. B: Lateral view. C: Ventral view. D: Variation of frontal appendage. 1. anterior pleural ridge, 2. upper pleural ridge, 3. anterior interlamellar mound, 4. upper ridge of tectopedia, 5. posterior interlamellar mound, 6. anterior corner above a slit, 7. upper end of rim, 8. posterior corner above a slit, 9. anterior cross ridge, 10. posterior cross ridge, 11. genal ridge, 12. lobe of acetabular tectum I, 13. acetabular tectum I, 14. pedotectum I, 15. lobe of acetabular tectum III.

border of crista short. Seta $t i$ slightly nearer to seta te than to seta $m s$; mutual distance of setae $t i$ narrow. Setae $r_{3}$ very near to seta $r_{2}$.

Material examined. Holotype (NSMT-Ac 10600 on slide) and five paratypes: Oasakacho, Matsuzaka-shi, Mie-ken, Japan, alt. 270m, 17-III-1991, N.Ohkubo.

Remarks. This is the most abundant Coronoquadroppia species in Central Japan. $Q$. circumita sensu Woas, 1985 may be this species. The following combination of charac- 
ters of this species can distinguish from other hitherto known congeners: (1) frontal appendage almost rectangular, (2) translamella long, but shorter than twice the width of lamellar plate, (3) mutual distance of notogastral setae $t i$ narrow, and (4) sternal groove III wide.

\section{Coronoquadroppia expansa sp. nov.}

(Fig. 2)

Measurements. Mean body length $209 \mu \mathrm{m}$ for three specimens; width $123 \mu \mathrm{m}$ for two specimens.

Prodorsum. Rostrum round. Rostral setae smooth. frontal appendage ovate from antero-dorsal view, widened anteriorly; posterior and lateral border strongly edged and irregularly dented; anterior border incomplete and obscure. Lamellar seta far shorter than width of lamellar plate, located under middle point of lamellar plate. Lamellar plate somewhat triangular with irregularly dentated border. Translamella connecting middle parts of lamellar plates, curving posteriad, as wide as or slightly wider than lamellar plate. Anterior interlamellar mounds somewhat trapezoidal.

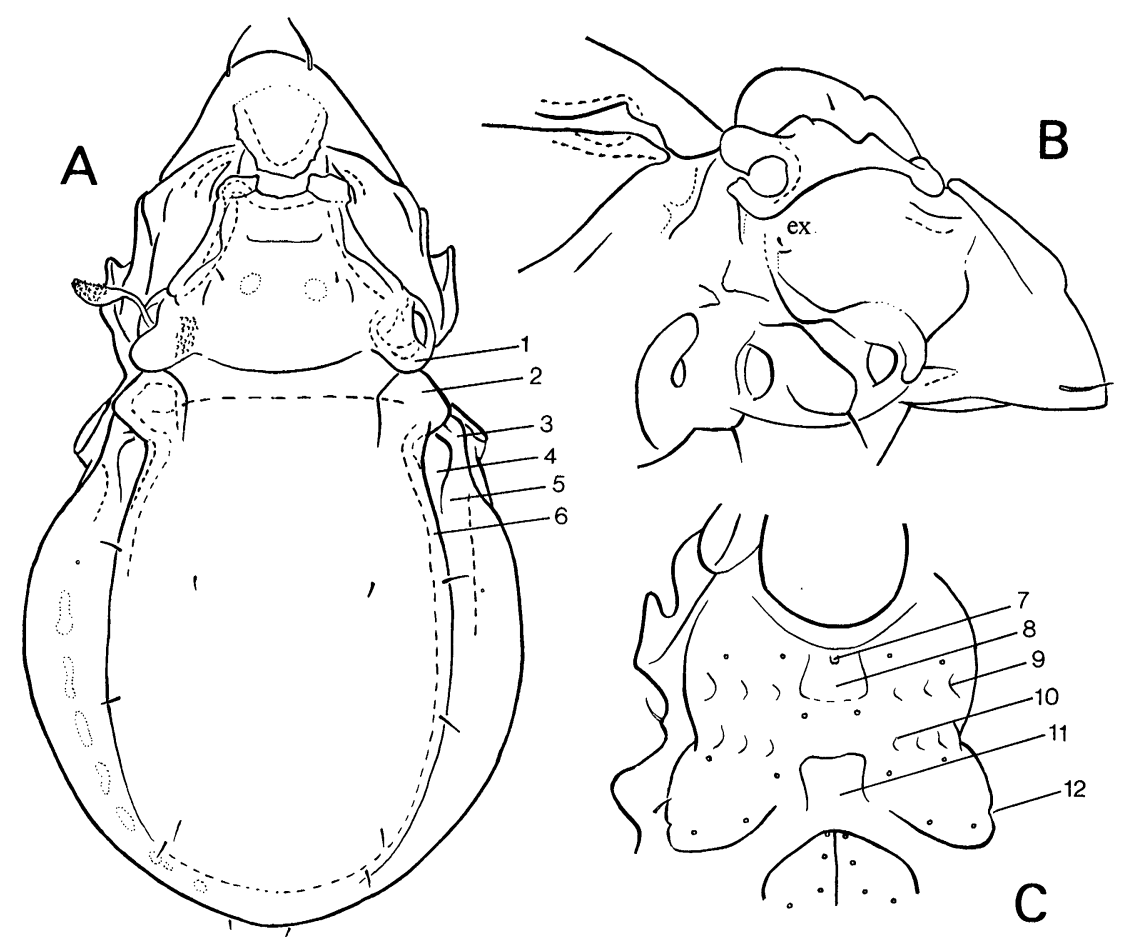

Fig. 2. Coronoquadroppia expansa sp.nov. A: Dorsal view. B: Lateral view of anterior part. C: Epimeral region. 1. bothridial protuberance, 2. notogastral crista, 3. humeral expansion, 4. notogastral groove, 5. exterior edge of groove, 6 . interior edge of groove, 7 . pit of sternal groove I, 8. sternal groove I, 9. pit of epimeral groove II, 10. pit of sejugal groove, 11. sternal groove III, 12. lateral constriction between epimera III and IV. 
Interlamellar setae minute. Upper pleural ridge crescent, almost touching the frontal appendage; its interior side deeply excavated to make a pocket. Anterior pleural ridge apart from frontal appendage in dorsal view, curving anteriad. Genal ridge short. Exobothridial seta minute.

Bothridium. Almost same as Q. parallela sp. nov., but posterior corner above a slit rather rounded.

Lateral podosoma. Same as Q. parallela sp. nov.

Epimeral region. Almost same as $Q$. parallela sp. nov., but a border between epimera III and IV barely detected by a lateral constriction.

Notogaster. Same as Q. parallela sp. nov.

Material examined. Holotype (NSMT-Ac 10606 on slide) and four paratypes: Mt. Akagisan, Gumma-ken, Japan, alt. about 1,500m, 17-V-1973, N.Ohkubo.

Remarks. The most remarkable feature of this new species is the shape of frontal appendage which is strongly expanded anteriorly. Some other species also has the expanded frontal appendage, but their degree of expansion is weaker.

\section{Acknowledgments}

I express my sincere thanks to Dr. L.S. Subías of Universidad Compultense de Madrid who gave me the paratypes of Quadroppia hammerae. I also indebted to Dr. M. Luxton of National Museums \& Galleries of Wales who informed me of the lectotype of Quadroppia quadricarinata.

摘 要

ヨスジダニ科の種リストおよび新属新種 大久保憲秀（三重県農業技術センター）

日本から新属のカンムリヨスジダニ属Coronoquadroppia と 2 新種ナミヨスジダニC. parallela (基準種), オウギヨスジダニC. expansa を記載した。ヨスジダニ科は本属とヨス ジダ二属（Quadroppia 和名改称）の 2 属から構成される。これまでに知られていた本科の 22 種 3 亜種を整理し，ヨスジダニ属から 15 種 1 亞種をカンムリヨスジダニ属に移した。

\section{REFERENCES}

Balogh, J. (1958): Oribatides nouvelles del'Afrique tropicale. Rev. Zool. Bot. Afr., 58(1-2): 1-34.

Balogh, J. and P. Balogh (1992): The Oribatid Mites Genera of the World, vol. 1. 263 p., Hung. Nat. Hist. Mus., Hungary.

Balogh, J. and S. Mahunka (1980): New data to the knowledge of the oribatid fauna of the Neogea (Acari). V. Acta Zool. Acad. Sci. Hung., 26: 21-59.

Balogh, J. (1983): A partial revision of the Oppiidae Grandjean, 1954 (Acari: Oribatei). Acta. Zool. Acad. Sci. Hung., 29(1-3): 1-79.

Berlese, A. (1896): Acari Myriopoda et Scorpiones hucusque in Italia reperta. Ordo Cryptostigmata (Oribatidae). Padova, 96 p., 11 tabs, 1 folds.

Gordeeva, E. V. (1983): Mites of the genus Quadroppia Jacot, 1939 (Oribatei, Oppiidae) from different regions of the Soviet Union. Zool. J., 62: 1267-1270. (in Russian with English summary) 
Gordeeva, E. V. and Z.M. Tarba (1990): New genus and species of Oppiidae (Acariformes, Oribatei) from Abkhaziya. Zool. J., 69: 143-147. (in Russian with English summary)

Hammer, M. (1961): Investigations on the oribatid fauna of the Andes Mountains. II. Peru. Biol. Skr. Dan. Vid. Selsk., 13(1): 1-157, pls. 1-43.

Hammer, M. (1968): Investigations on the oribatid fauna of New Zealand with a comparison between the oribatid fauna of New Zealand and that of the Andes Mountains, South America. Part III. Biol. Skr. Dan. Vid. Selsk., 16(2): 1-96, pls. 1-33.

Hammer, M. (1979): Investigations on the oribatid fauna of the Java. Biol. Skr. Dan. Vid. Selsk., 22 (9): 1-78, pls. 1-47.

Jacot, A.P. (1938a): Some new Western North Carolina moss-mites. Proc. Ent. Soc. Wash., 40: 10-15. Jacot, A.P. (1938b): New moss-mites, chiefly Midwestern III. Amer. Midl. Nat., 19: 647-657.

Jacot, A.P. (1939): New mites from the White Mountains. Occ. Papers, Boston Soc. Nat. Hist., 8: 321332.

Lions, J.-C. (1978): Au sujet de la chaetotaxie des pattes et de la presence des poils proraux chez des oribates proches du Quadroppia quadricarinata (Michael, 1885). Acarologia, 19: 540-551.

Lions, J.-C. (1982): Statistique sexuelle cehz deux formes d'oribates proches du Quadroppia quadricarinata (Michael, 1885). Acarologia, 23: 373-389.

Luxton, M. (1987): Oribatid mites (Acari: Cryptostigmata) from the Isle of Man. Naturalist, 112: 6777.

Mahunka, S. (1977): Neue und interessante Milben aus dem Genfer Museum XXX. Weitere Beitrage zur Kenntnis der Oribatiden-Fauna Griechenlands (Acari: Oribatida). Revue suisse Zool., 84: 905916.

Mahunka, S. (1984): Oribatids of the eastern part of the ethiopian region (Acari) V. Acta Zool. Hung., 30: 87-136.

Mahunka, S. and M.G. Paoletti (1984): Oribatid mites and other mites (Tarsonemidae, Anoetidae, Acaridae) from woods and farms monocultivated with corn in the low laying plain (Veneto and Friuli, N-E Italy). Redia, 67: 93-128.

Michael, A. D. (1885): New British Oribatidæ. J. Roy. Micr. Soc. London, ser. 2., 5: 385-397, pl. 7.

Michael, A. D. (1888): British Oribatidæ. Vol. II. Ray. Soc., London, p. 337-657.

Mínguez, M.E., E. Ruiz and L.S. Subías (1985): El género Quadroppia Jacot, 1939, (Acari, Oribatida, Oppiidae). Boletin Asoc. esp. Entom., 9: 95-118.

Paoli, G. (1908): Monografia del genere Dameosoma Ber. e generi affini. Redia, 5: 31-91, pls. 3-5.

Seniczak, S. (1975): Revision of the family Oppiidae Grandjean 1953 (Acarina, Oribatei). Acarologia, 17: $331-345$.

Subías, L.S. and P. Rodríguez (1986): Oppiidae (Acari: Oribatida) de los sabinares (de Juniperus thuripera) de España, IV. Subfamilias Mystroppiinae Balogh y Quadroppiinae Balogh. Anal. Biol., 7 (biol. amimal 2): 37-45.

Woas, S. (1986): Beitrag zur Revision der Oppioidea sensu Balogh, 1972 (Acari, Oribatei). Andrias, 5: 21-224.

Willmann, C. (1931): Moosmilben oder Oribatiden (Oribatei). In Dahl, F. ed. Die Tierwelt Deutschlands, 22: 79-200. 